\title{
Evaluation of Suitable Nutrient Management on Dual Purpose Flax (Linum usitatissimum L.) Crop under New Alluvial Zone (NAZ) of West Bengal, India
}

\author{
Sirajul Islam ${ }^{1}$, D.C. Roy ${ }^{2}$, M. Pramanik ${ }^{3}$, A. Saha ${ }^{4}$, K. Sengupta ${ }^{3}$, A. Das ${ }^{3}$, \\ T.K. Sarkar ${ }^{3}$, S. Mitra ${ }^{1}$, R.K. Naik ${ }^{1}$, S.K. Pandey ${ }^{1}$ and S.C. Saha ${ }^{5}$ \\ ${ }^{1}$ ICAR-CRIJAF, Nilganj, Barrackpore, West Bengal-700120, India \\ ${ }^{2}$ Department of LFC, WBUAFS, Mohanpur, West Bengal-741252, India \\ ${ }^{3}$ Department of Agronomy, BCKV, Mohanpur, West Bengal-741252, India \\ ${ }^{4}$ College of Agriculture, Lembucherra, Tripura-799210, India \\ ${ }^{5}$ ICAR-NIRJAFT, Kolkata, West Bengal-700040, India \\ *Corresponding author
}

\section{A B S T R A C T}

A field experiment was conducted at BCKV, Mohanpur, West Bengal during rabi, 201617 to study the effect of different combination of nutrients on quality fibre and seed production of dual purpose flax crop. The experiment was in RBD with eight treatments, replicated thrice. The treatment combinations were, $\mathrm{T}_{1}=100 \%$ recommended dose of

\section{Keywords}

Flax, Fibre, RDN, Basal diameter, Fineness, Strength

Article Info

Accepted:

04 April 2018

Available Online:

10 May 2018 nitrogen (RDN) from organic sources (mustard cake, FYM, vermicompost, bone meal and liquid manures), $\mathrm{T}_{2}=125 \% \mathrm{RDN}$ from organic sources, $\mathrm{T}_{3}=75 \% \mathrm{RDN}$ from organic sources $+25 \%$ RDN from chemical fertilizer sources (Urea, SSP and MOP), $\mathrm{T}_{4}=50 \%$ RDN from organic sources $+50 \%$ RDN from chemical fertilizer sources, $\mathrm{T}_{5}=100 \% \mathrm{RDN}$ from chemical fertilizer sources, $\mathrm{T}_{6}=125 \% \mathrm{RDN}$ from chemical fertilizer sources, $\mathrm{T}_{7}=$ $75 \%$ RDN from chemical fertilizer sources $+25 \%$ RDN from organic sources and $\mathrm{T}_{8}=$ Control. Highest plant height $(147.20 \mathrm{~cm})$ was recorded in $\mathrm{T}_{2}$ though highest basal diameter $(0.69 \mathrm{~cm})$ was observed in $\mathrm{T}_{6}$. Seed yield was significantly highest $\left(15.40 \mathrm{q} \mathrm{ha}^{-1}\right)$ in $\mathrm{T}_{2}$, followed by $\mathrm{T}_{1}$ and $\mathrm{T}_{3}$. Similarly highest fibre yield of $19.13 \mathrm{q} \mathrm{ha}^{-1}$ was obtained in $\mathrm{T}_{2}$. However significantly lowest plant height, basal diameter, seed as well as fibre yield were recorded in control plots. Regarding fibre quality, better quality fibre with least fineness $\left(2.97\right.$ tex) was recorded in $\mathrm{T}_{2}$ whereas fibre with least strength was found in $\mathrm{T}_{7}$ though it was at par with $\mathrm{T}_{2}$. Inferior quality fibre was obtained in control plots. From the observed data it can be recommended that dual purpose flax with $125 \%$ of recommended dose of nitrogen (RDN) from different organic sources produce higher yield of both better quality flax fibre and seed under NAZ of West Bengal.

\section{Introduction}

Flax (Linum usitatissimum L.) indeed has many uses in the field of industry, food, feed and even in the medical sector especially for diabetic and heart patients. Flax, which has been grown throughout the world for millennia, is the source of products for 
existing, high-value markets in the textile, composites, paper/pulp, and also industrial/ nutritional oil sectors. Fine and regular long flax fibres are spun into yarns for linen textiles. More than $70 \%$ of linen goes to clothing manufacture, where it is valued for its exceptional coolness in hot weather. It absorbs and releases water quickly, making linen comfortable to wear in hot weather. Like other crops, nutrients like nitrogen, phosphorus, potash etc. are the main limiting factors that regulate the increase or decrease of yield and quality of flax seed as well as fibre.

Flax is a new crop of dual purpose type providing both seed and fibre in the eastern part of our country and has immense scope for profit maximization for the farmers of this agro-climatic zone. The above experiment was conducted to assess the suitable nutrient management practice for sustainable production of quality fibre as well as seed of flax.

\section{Materials and Methods}

The experiment was conducted at the Instructional Farm (Latitude 22 $56^{\prime \prime} \mathrm{N}$, Longitude $88^{\circ} 32^{\prime \prime}$ E), Bidhan Chandra Krishi Viswavidyalaya, Mohanpur, Nadia, West Bengal. Soil of the experiment site was loamy soil with $\mathrm{pH}$ ranges $7.0-7.2$, Organic carbon$0.561 \%$, Nitrogen-0.052 \%, available P$35 \mathrm{~kg} / \mathrm{ha}$ and available $\mathrm{K}-23.15 \mathrm{~kg} / \mathrm{ha}$. The experiment was laid out in Randomized Block Design with 8 (Eight) treatment combinations and 3 replications. The treatment combinations were $: \mathrm{T} 1=100 \%$ recommended dose of nitrogen (RDN) from organic sources (mustard cake, FYM, vermicompost, bone meal and liquid manures), $\mathrm{T} 2=125 \% \mathrm{RDN}$ from same organic sources, $\mathrm{T} 3=75 \% \mathrm{RDN}$ from same organic sources $+25 \%$ RDN from chemical fertilizer sources (Urea, SSP and $\mathrm{MOP}), \mathrm{T} 4=50 \% \mathrm{RDN}$ from same organic sources $+50 \%$ RDN from the same chemical fertilizer sources, T5 $=100 \%$ RDN from same chemical fertilizer sources, T6 $=125 \%$ RDN from same chemical fertilizer sources, T7= $75 \%$ RDN from same chemical fertilizer sources+25\% RDN from same organic sources and $\mathrm{T} 8=$ Control. Mustard cake, FYM, vermicompost, bone meal and liquid manures were used as organic source of nutrients whereas Urea, SSP and MOP were used as inorganic sources. Liquid manure was prepared by mixing fresh cow dung, cow urine, besan (powder of pulses) and molasses with 100 litre of water in the ratio of 10:10:2:2 and by keeping the mixture in earthen pot for fermentation. After 7 days said solution was sprayed on the foliage of the crop. Plant height, basal diameter, dry biomass were recorded at the harvesting stage of the crop. Harvesting of flax was done when 80-90\% capsules became yellow or golden brown. Plants were left in the field after harvesting for 2-3 days, then dipped into water in retting tank after separating the seeds and fibre extraction was done through alternate retting and sun drying. Fibre extraction was done by using ICAR-CRIJAF (Indian Council of Agricultural Research - Central Research Institute for Jute and Allied Fibre) flax extractor (scotching machine).

Fibre fineness and strength were estimated by using airflow fineness tester and fibre bundle strength tester respectively. Benefit: cost ratio was calculated by applying the formula gross return/total cost of cultivation. Statistical calculation regarding design of experiment was done by using methodology as described in Rangaswamy (2014). Correlations were estimated as suggested by Al-Jibouri et al., (1958).

\section{Results and Discussion}

\section{Plant height}

Significant effect of different nutrient 
combinations on plant height was observed in the experiment (Table 1).

Highest plant height of $147.2 \mathrm{~cm}$ was recorded in $\mathrm{T}_{2}$ i.e., $125 \%$ recommended dose of nitrogen (RDN) supplied from different organic sources (like mustard cake, FYM, vermicompost, bone meal and liquid manure) though it was statistically at par with $\mathrm{T}_{1}$ i.e., $100 \%$ recommended dose of nitrogen (RDN) supplied from different organic sources which might be due to higher levels of available nutrients supplied from organic sources specially from liquid manure. Significantly lowest plant height $(81.33 \mathrm{~cm})$ was observed from control plot.

Similar result was also obtained by the scientists of ICAR-CRIJAF, West Bengal (Anonymous, 2016).

\section{Basal diameter}

Effect of sole organic, sole inorganic and combination of organic and inorganic sources of nitrogen on basal diameter of flax was found statistically significant (Table 1). Significantly higher basal diameter (0.69 $\mathrm{cm}$ ) was obtained in $\mathrm{T}_{6}$ i.e., $125 \% \mathrm{RDN}$ from same chemical fertilizer sources followed by $\mathrm{T}_{2}$ (Table 1).

Similar result was also obtained by the scientists of ICAR-CRIJAF, West Bengal (Anonymous, 2016).

\section{Dry biomass}

Significantly highest dry biomass $(68.0 \mathrm{q}$ $\left.\mathrm{ha}^{-1}\right)$ at harvesting was obtained in $\mathrm{T}_{2}(125 \%$ recommended dose of nitrogen (RDN) supplied from different organic sources) followed by $\mathrm{T}_{5}(100 \% \mathrm{RDN}$ from chemical fertilizer sources) andT 4 (50\% RDN from organic sources $+50 \%$ RDN from the chemical fertilizer sources) (Table 1).
However, control plots showed the least performance (19.36 $\left.\mathrm{q} \mathrm{ha}^{-1}\right)$.

\section{Seed yield}

Different combination of sources of nitrogen gave significant effect on seed yield of flax. Highest seed yield of $15.40 \mathrm{q} \mathrm{ha}^{-1}$ was obtained in $\mathrm{T}_{2}$ (125\% recommended dose of nitrogen supplied from different organic sources) which was statistically at par with $\mathrm{T}_{1}, \mathrm{~T}_{3}, \mathrm{~T}_{4}$, and $\mathrm{T}_{6}$ and significantly higher over control (3.75 q ha ${ }^{-1}$ ) (Table 1) which might be due to the fact that plants of $T_{2}$ plots had higher plant height, comparatively greater basal diameter that indicated more number of tillers and branches, higher number of capsules per plant etc.

\section{Fibre yield}

Like seed yield, fibre yield of flax was also significantly influenced by different combination of sources of nitrogen.

Highest fibre yield (19.13 q ha $\left.{ }^{-1}\right)$ was obtained in $\mathrm{T}_{2}$ (125\% recommended dose of nitrogen (RDN) supplied from different organic sources) which was statistically significant over other treatments (Table 1).

Similar observation was also reported by Tripathi and Chaudhary (2015).

\section{Fibre quality}

Best quality fibre with least fineness (2.97 tex) was obtained in $\mathrm{T}_{2}$ i.e., $125 \%$ recommended dose of nitrogen (RDN) supplied from different organic sources which was statistically significant over control (Table 1) and it might be due to singleness/separation of individual fibre from each other. 


\section{Int.J.Curr.Microbiol.App.Sci (2018) 7(5): 8-14}

Table.1 Effect of different nutrient management practices on plant growth, seed yield and fibre yield of flax

\begin{tabular}{|c|c|c|c|c|c|c|c|c|}
\hline Treatments & $\begin{array}{l}\text { Plant height } \\
\text { (cm) }\end{array}$ & $\begin{array}{l}\text { Basal } \\
\text { diameter } \\
(\mathrm{cm})\end{array}$ & $\begin{array}{l}\text { Dry biomass } \\
\qquad\left(\mathbf{q ~ h \mathbf { a } ^ { - 1 } )}\right.\end{array}$ & $\begin{array}{l}\text { Seed yield } \\
\qquad\left(\mathbf{q} \mathbf{h a}^{-1}\right)\end{array}$ & $\begin{array}{l}\text { Fibre yield } \\
\qquad\left(\mathbf{q} \mathbf{h a}^{-1}\right)\end{array}$ & $\begin{array}{l}\text { Fibre } \\
\text { strength } \\
\left(\mathrm{g} \mathrm{tex}^{-1}\right)\end{array}$ & $\begin{array}{c}\text { Fibre } \\
\text { fineness } \\
\text { (tex) }\end{array}$ & $\mathbf{B}: \mathbf{C}$ \\
\hline $\mathbf{T 1}$ & 143.93 & 0.55 & 60.88 & 13.87 & 15.27 & 23.79 & 3.16 & 1.95 \\
\hline $\mathrm{T} 2$ & 147.20 & 0.63 & 68.00 & 15.40 & 19.13 & 25.34 & 2.97 & 2.10 \\
\hline T3 & 138.93 & 0.58 & 57.65 & 13.85 & 15.41 & 21.39 & 4.27 & 1.97 \\
\hline $\mathrm{T} 4$ & 138.47 & 0.60 & 62.69 & 12.67 & 15.93 & 23.26 & 3.14 & 2.04 \\
\hline T5 & 137.33 & 0.63 & 64.64 & 12.40 & 16.51 & 23.32 & 4.56 & 2.04 \\
\hline T6 & 137.07 & 0.69 & 50.83 & 12.64 & 13.44 & 22.01 & 3.39 & 1.82 \\
\hline T7 & 138.67 & 0.63 & 59.96 & 11.87 & 14.92 & 19.67 & 5.02 & 1.60 \\
\hline T8 & 81.33 & 0.23 & 19.36 & 3.75 & 3.47 & 30.29 & 5.17 & 0.53 \\
\hline S.Em ( \pm$)$ & 1.747 & 0.073 & 1.204 & 0.946 & 0.978 & 1.048 & 0.863 & - \\
\hline $\mathrm{CD}(5 \%)$ & 5.292 & 0.223 & 3.652 & 2.869 & 2.967 & 3.177 & 2.616 & - \\
\hline
\end{tabular}


Table.2 Correlation coefficient in seed yield and fibre yield of flax

\begin{tabular}{|l|c|c|}
\hline Parameters & Seed yield & Fibre yield \\
\hline Plant height & $0.982 * *$ & $0.965 * *$ \\
\hline Basal diameter & $0.872 * *$ & $0.873 * *$ \\
\hline Dry biomass & $0.939 * *$ & $0.989 * *$ \\
\hline Seed yield & - & $0.964 * *$ \\
\hline Fibre yield & $0.964 * *$ & - \\
\hline Fibre fineness & $(-) 0.677$ & $(-) 0.588$ \\
\hline Fibre strength & $(-) 0.707$ & $(-) 0.628$ \\
\hline
\end{tabular}

*significant at $5 \%$ level $* *$ significant at $1 \%$ level

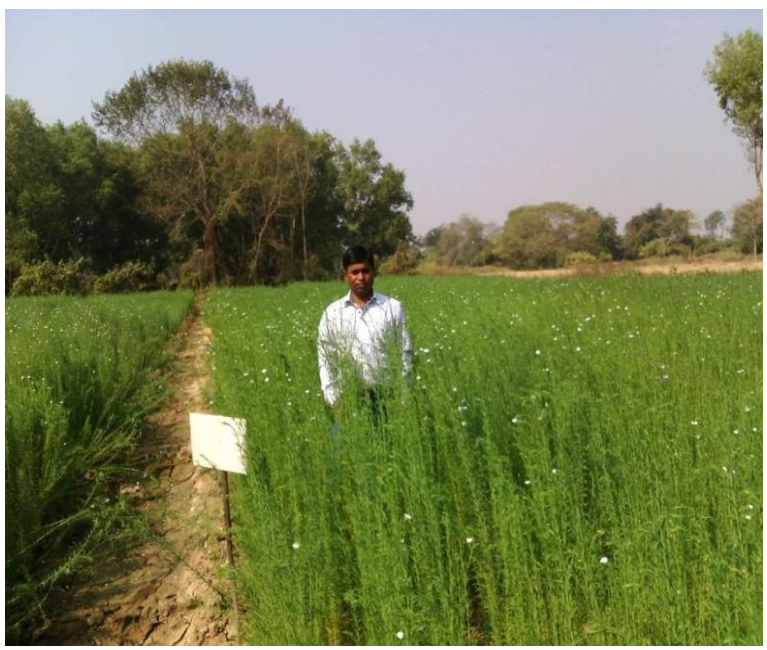

Fig. 2 Flax crop at flower initiation stage

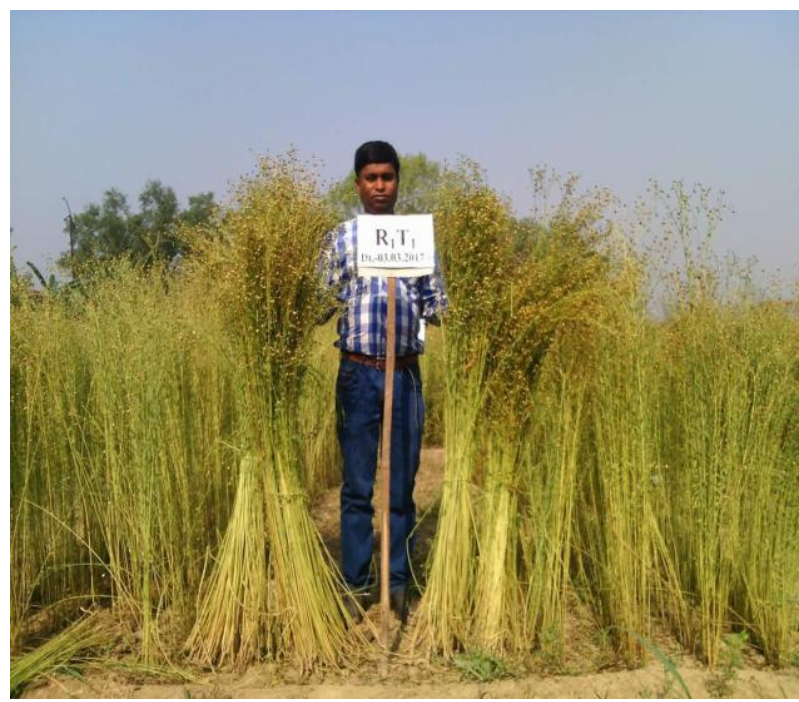

Fig. 4 Flax crop at harvesting

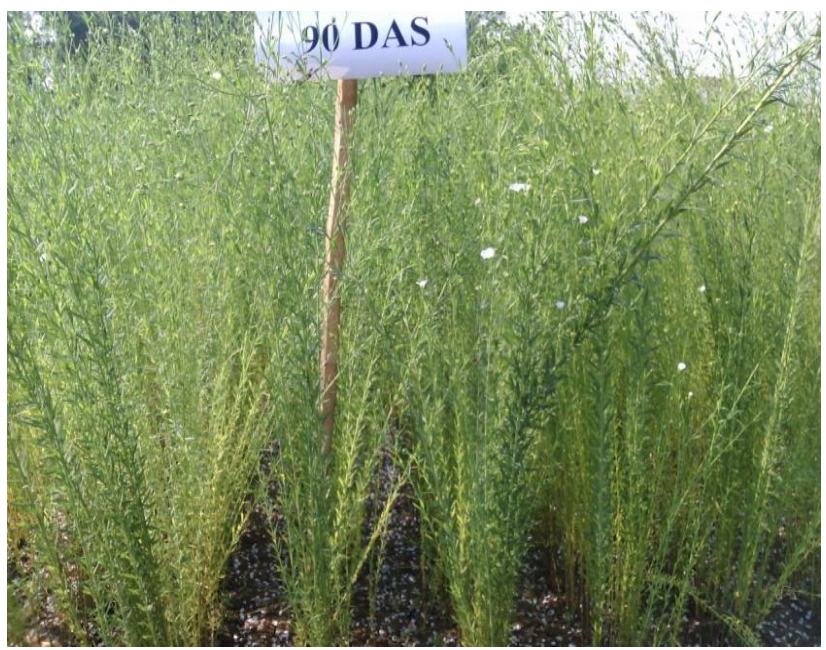

Fig. 1 Flax crop at flowering

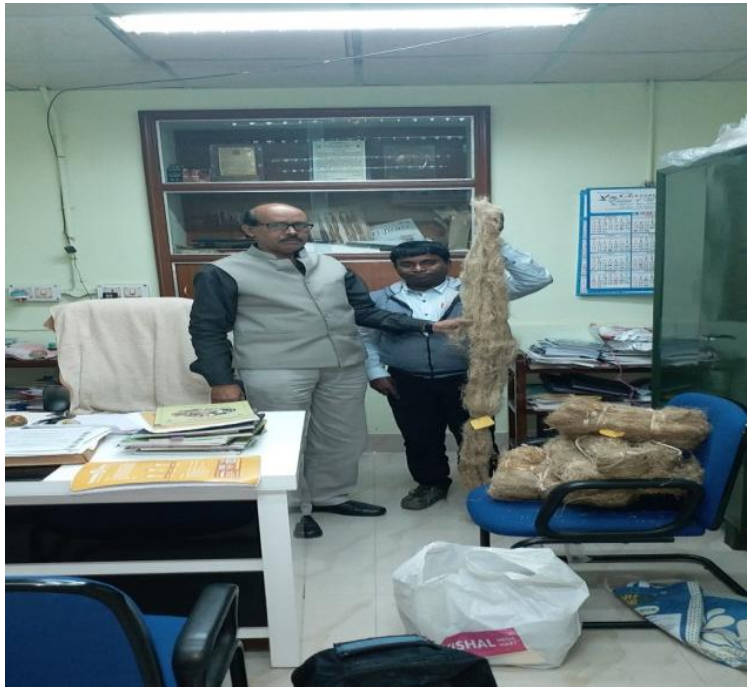

Fig. 3 Flax fibre after extraction 
However, strength of fibre of flax ranges 20-30 $\mathrm{g} \mathrm{tex}^{-1}$ value indicates better quality fibre and the value of $25.34 \mathrm{~g} \mathrm{tex}^{-1}$ (Table 1 was recorded in $\mathrm{T}_{2}$ i.e., $125 \%$ recommended dose of nitrogen (RDN) supplied from different organic sources followed by $\mathrm{T}_{1}, \mathrm{~T}_{5}$ and $\mathrm{T}_{4}$ though which was statistically at par with $\mathrm{T}_{2}$.

\section{Correlation of seed yield with other parameters}

From the observed data it was found that a positive and significant $(\mathrm{p}=0.01)$ correlation existed between seed yield and plant height, basal diameter, dry biomass and fibre yield of flax (Table 2). However a negative and not significant correlation was obtained between seed yield and fibre quality like fineness and strength of fibre.

\section{Correlation of fibre yield with other parameters}

In case of fibre yield also, a positive and significant $\quad(p=0.01)$ correlation existed between fibre yield and plant height, basal diameter, dry biomass and seed yield of flax. However a negative and not significant correlation was obtained between fibre yield and fibre quality like fineness and strength of fibre (Table 2).

\section{Economics}

Regarding the economic profitability of the different combination of sources of nutrients, higher benefit cost ratio were obtained in sole organic, sole inorganic and organic + inorganic treatments than control plots. Comparatively higher benefit cost ratio of 2.10:1 was obtained in $\mathrm{T}_{2}$ i.e., $125 \%$ recommended dose of nitrogen (RDN) supplied from different organic sources followed by $\mathrm{T}_{4}$ and $\mathrm{T}_{5}, \mathrm{~T}_{1}, \mathrm{~T}_{3}$ which might be due to higher seed and fibre yield in $\mathrm{T}_{2}$.
Benefit cost ratio was lowest in control plot (0.53) (Table 1).

From the observed data it was found that sole organic sources of nitrogen showed significant effect on plant growth, seed yield, fibre yield and fibre quality over sole inorganic sources or combination of inorganic and organic sources of nitrogen on flax. Better performance regarding plant growth, seed and fibre yield, fibre quality and benefit-cost ratio was recorded in $T_{2}$ i.e., $125 \%$ recommended dose of nitrogen (RDN) supplied from different organic sources. Plant characters like plant height, basal diameter and dry biomass showed positive and significant relationship with both seed yield and fibre yield whereas fibre quality like fibre fineness and strength had negative and not significant effect on these. Thus, it can be recommended that application of $125 \%$ recommended dose of nitrogen (RDN) supplied from different organic sources (like mustard cake, FYM, vermicompost, bone meal and liquid manure) may give higher yields of seed and fibre coupled with superior quality fibre of flax under New Alluvial Zone (NAZ) of West Bengal.

\section{Acknowledgement}

The authors acknowledge the authorities and officials of BCKV for providing the necessary facilities for conducting the experiments.

\section{References}

Al-jibouri, H. A., Miller, P.A, and Robinson, H.F. 1958. Genotypic and environmental variances and covariances in an upland cotton cross of interspecific origin. Agron. J., 50: 633- 637. 
Anonymous 2016. Fibre yield maximization in Flax (Linum usitatissimum L.). AINP report (2015-16): 128-132.

Rangaswamy, R.A 2014. In. Text book of Agricultural Statistics (2 ${ }^{\text {nd }}$ Edition),
New Age International (P) Ltd., Publishers, New Delhi. pp. 141-314. Tripathi, M.K. and Chaudhary, B. 2015.In. Effect of NPK on growth and yield of Flax (Linum usitatissimum L.). Annual Report (2014-15), pp. 122-123.

\section{How to cite this article:}

Sirajul Islam, D.C. Roy, M. Pramanik, A. Saha, K. Sengupta, A. Das, T.K. Sarkar, S. Mitra, R. K. Naik, S.K. Pandey and Saha, S.C. 2018. Evaluation of Suitable Nutrient Management on Dual Purpose Flax (Linum usitatissimum L.) Crop under New Alluvial Zone (NAZ) of West Bengal, India. Int.J.Curr.Microbiol.App.Sci. 7(05): 8-14. doi: https://doi.org/10.20546/ijcmas.2018.705.002 